\title{
SHORT REPORT: FIRST REPORT OF KNOCKDOWN MUTATIONS IN THE MALARIA VECTOR ANOPHELES GAMBIAE FROM CAMEROON
}

\author{
JOSIANE ETANG, ETIENNE FONDJO, FABRICE CHANDRE, ISABELLE MORLAIS, CECILE BRENGUES, \\ PHILIPPE NWANE, MOUHAMADOU CHOUAIBOU, HAMADOU NDJEMAI, AND FRÉDÉRIC SIMARD* \\ Organisation de Coordination pour la Lutte contre les Endémies en Afrique Centrale, Yaounde, Cameroon; Institute of Medical \\ Research and Studies of Medicinal Plants, Ministry of Scientific Research and Innovation, Yaounde, Cameroon; National Malaria \\ Control Program, Ministry of Health, Yaounde, Cameroon; Centre de Recherches Entomologiques de Cotonou, Cotonou, Benin; \\ Institut de Recherche pour le Développement, Research Unit 016, Montpellier, France
}

\begin{abstract}
We report the first finding of the knockdown Leu-Phe and Leu-Ser mutations associated with resistance to pyrethroids and DDT insecticides in the malaria mosquito Anopheles gambiae from Cameroon. The Leu-Phe mutation was found in both the $\mathrm{M}$ and $\mathrm{S}$ molecular forms of An. gambiae. Importantly, two specimens of the S molecular form were found to carry both mutations in a heterozygous state.
\end{abstract}

The spread of pyrethroid resistance in Anopheles gambiae is a major concern for malaria prevention in Africa, which essentially relies on the use of insecticide treated materials or indoor residual spraying. ${ }^{1}$ Resistance mechanisms include metabolic detoxification through increased enzyme activities and target site insensitivity due to mutations at the DNA level. ${ }^{2}$ One of the most well-characterized pyrethroid resistance mechanisms in An. gambiae is due to a single nucleotide polymorphism in the gene encoding subunit 2 of the sodium channel. This mutation, known as the knockdown $(k d r)$ mutation, leads to the substitution of a leucine (TTA) for phenylalanine (TTT) and is widespread in west Africa, where it is strongly associated with the $\mathrm{S}$ molecular form of An. gambiae. $^{3,4}$

More recently, a second $k d r$ mutation in the same amino acid, changing the leucine (TTA) to a serine (TCA) was described from east African populations. ${ }^{5}$ Although data on malaria vector susceptibility to insecticides are scarce for countries in central Africa, recent surveys conducted in Cameroon demonstrated various levels of resistance in An. gambiae populations from Cameroon, but $k d r$ mutations were never detected. ${ }^{6-8}$ Here, we report heterogeneous patterns of resistance to DDT and pyrethroids in three areas in Cameroon. We also provide the first evidence for $k d r$ mutations in both the $\mathrm{M}$ and $\mathrm{S}$ forms of An. gambiae s.s.

The survey was undertaken between May 2003 and September 2004. Mosquito larvae were collected in three areas: 1) Foumbot $\left(5^{\circ} 31^{\prime} \mathrm{N}, 10^{\circ} 37^{\prime} \mathrm{E}\right)$, an area of intensive gardening in the mountain grasslands of the western region (altitude = $1,100$ meters, mean annual rainfall $=1,721 \mathrm{~mm}), 2$ ) Bonassama district $\left(3^{\circ} 51^{\prime} \mathrm{N}, 10^{\circ} 08^{\prime} \mathrm{E}\right)$ in Douala, a city in the northern coastal region (altitude $=18$ meters, mean annual rainfall $=4,110 \mathrm{~mm})$, and 3) Campo $\left(2^{\circ} 22^{\prime} \mathrm{N}, 9^{\circ} 50^{\prime} \mathrm{E}\right)$ in the southern coastal region (altitude $=25$ meters, mean annual rainfall $=2,804 \mathrm{~mm}$ ). Field-collected larvae were reared to adults, and emerging specimens were identified morphologically. ${ }^{9}$ Susceptibility of field An. gambiae populations to $4 \%$ DDT, $1 \%$ permethrin, $0.05 \%$ deltamethrin, or $0.05 \%$ lambdacyhalothrin was assessed using World Health Organization (Geneva, Switzerland) test kits according to standardized procedures. $^{10}$

* Address correspondence to Frédéric Simard, Organisation de Coordination pour la Lutte contre les Endémies en Afrique Centrale, PO Box 288, Yaounde, Cameroon. E-mail: simard@ird.fr
Times for $50 \%$ knockdown $\left(\mathrm{KdT}_{50}\right)$ and mortality rates 24 hours post-exposure are shown in Table 1. Resistance to DDT was observed in Foumbot and Douala with less than $35 \%$ mortality rates and increased $\mathrm{KdT}_{50}$ up to the loss of the knockdown effect in Foumbot. This population was also resistant to permethrin and deltamethrin (50-90\% mortality) while in Douala, mosquitoes were resistant to lambdacyhalothrin ( $90 \%$ mortality) but susceptible to deltamethrin. In Campo, a slight decrease in susceptibility to DDT and permethrin (>95\% mortality) was observed.

DNA was extracted from survivors to the bioassays and from at least 30 (unexposed) control specimens per site. Mosquito species and molecular forms were simultaneously determined using a polymerase chain reaction-restriction fragment length polymorphism (PCR-RFLP) assay. ${ }^{11}$ All mosquitoes tested were An. gambiae s.s., in agreement with the known geographic distribution of species within the An. gambiae complex in Africa. ${ }^{12}$ Only the $\mathrm{S}$ molecular form was found in the Foumbot sample $(\mathrm{n}=60)$, while all specimens from Douala were of the $M$ form $(n=80)$. In Campo, both molecular forms were found $(\mathrm{n}=60)$ and no hybrid was observed, as previously reported in Cameroon. ${ }^{13}$ The $\mathrm{S}$ form was predominant ( 46 of $60=77 \%$ ) over the M form (14 of $60=23 \%)$.

The $k d r$ genotypes of survivors were determined using the recently described hot ligation assay (HOLA). ${ }^{14} \mathrm{~A}$ high frequency of the $k d r$ Leu-Phe mutation was observed in $\mathrm{S}$ form mosquitoes from Foumbot; 21 of 27 survivors showed the resistant allele in the homozygous state. Similar findings were

TABLE 1

Knockdown times and mortality rates in field populations of Anopheles gambiae s.s. in Cameroon to 4\% DDT, 1\% permethrin and $0.05 \%$ deltamethrin or $0.05 \%$ lambdacyhalothrin*

\begin{tabular}{clrcr}
\hline Sites & \multicolumn{1}{c}{ Insecticides } & No. & $\begin{array}{c}\mathrm{KdT}_{50} \\
(95 \% \mathrm{CI})\end{array}$ & $\begin{array}{c}\text { Mortality } \\
(\%)\end{array}$ \\
\hline Foumbot & 4\% DDT & 162 & No Kd & 6.8 \\
& 1\% permethrin & 159 & $61.0(55.3-75.2)$ & 54.7 \\
& 0.05\% deltamethrin & 165 & $22.5(21.7-23.3)$ & 87.9 \\
Douala & 4\% DDT & 100 & $58.0(53.3-64.7)$ & 32.3 \\
& 0.05\% lambdacyhalothrin & 99 & $11.7(11.0-12.3)$ & 90.9 \\
& 0.05\% deltamethrin & 100 & $7.3(6.7-7.8)$ & 100 \\
Campo & 4\% DDT & 157 & $29.1(21.8-33.6)$ & 96.8 \\
& 1\% permethrin & 159 & $10.0(8.4-11.5)$ & 99.4 \\
& 0.05\% deltamethrin & 158 & $8.4(5.8-10.7)$ & 100 \\
\hline$* \mathrm{KdT}_{50}=$ & knockdown time (minutes) for $50 \%$ of mosquitoes; $\mathrm{CI}=$ confidence interval;
\end{tabular}

mortality $=$ mortality rate 24 hours post-exposure. 
TABLE 2

Knockdown $(K d r)$ genotypes in $\mathrm{M}$ and $\mathrm{S}$ molecular forms of Anopheles gambiae s.s. surviving exposure to insecticides in Cameroon

\begin{tabular}{lccc}
\hline \multicolumn{1}{c}{ Kdr genotype* } & $\begin{array}{c}\text { Foumbot } \\
\text { (S form) }\end{array}$ & $\begin{array}{c}\text { Douala } \\
\text { (M form) }\end{array}$ & $\begin{array}{c}\text { Campo } \\
\text { (S form) }\end{array}$ \\
\hline TTA/TTA (SS) & 1 & 7 & 2 \\
TTA/TTT (SRw) & 1 & 3 & 4 \\
TTA/TCA (SRe) & 1 & 0 & 0 \\
TTT/TTT (RwRw) & 3 & 0 & 0 \\
TTT/TCA (RwRe) & 2 & 0 & 0 \\
TCA/TCA (ReRe) & 1 & 0 & 0 \\
Total & 9 & 10 & 6 \\
\hline * $=$ susceptible allele, Rw $=$ kdr leucine-phenylalanine allele, Re $=$ kdr leucine-serine
\end{tabular}
allele.

reported in several west African countries. ${ }^{4,7,15,16}$ Moreover, two specimens from this sample displayed both $k d r$ Leu-Phe and Leu-Ser alleles in a heterozygous state. The $k d r$ Leu-Phe allele was also observed in $\mathrm{S}$ form mosquitoes from Campo and in the $\mathrm{M}$ form from Douala, although at lower frequencies (6 of 21 and 3 of 41 specimens, respectively) and only in the heterozygous state. The PCR products of 25 specimens from the three areas were cloned using the Topo TA cloning kit (Invitrogen, Carlsbad, CA) and sequenced using primer $\mathrm{T} 7$ to confirm results obtained with the HOLA assay on a representative sample. As expected, the resistant alleles were characterized by an $\mathrm{A} \rightarrow \mathrm{T}$ or $\mathrm{T} \rightarrow \mathrm{C}$ substitution (Table 2), leading to Leu-Phe and Leu-Ser substitutions, respectively, at the protein level. These results validated the HOLA protocol for use in An. gambiae field specimens from Cameroon. Investigations are underway to provide more precise assessment of the frequency and geographic distribution of both $k d r$ mutations in wild An. gambiae populations from Cameroon.

Our data suggest that DDT and pyrethroid resistance in An. gambiae from Foumbot is mainly due to $k d r$ mutations. However, lower allelic frequencies of $k d r$ in coastal areas indicate that other resistance mechanisms are involved, such as metabolic detoxification, especially in Douala where high levels of glutathione S-transferase and esterase activities were previously reported (Etang $\mathrm{J}$, unpublished data). Together with recent reports of the $k d r$ Leu-Phe mutation in the $\mathrm{M}$ form of An. gambiae from neighboring Benin and the Central African Republic, ${ }^{17}$ Nigeria, ${ }^{18}$ and the island of Bioko, ${ }^{8}$ the present report from Cameroon confirms the ongoing spread of $k d r$-based pyrethroid resistance in Africa. This emphasizes the need for close monitoring of resistance to elaborate appropriate strategies for malaria vector control.

Received December 13, 2005. Accepted for publication January 11, 2006.

Acknowledgments: We thank J.-C. Toto and S. Patchoké for technical assistance during mosquito collections and bioassays.

Financial support: This study was supported by the World Health Organization/Tropical Disease Research/Mulilateral Initiative on Malaria within the framework of the "Network for the Study of the Factors Conditioning Evolution of Pyrethroid Resistance in Anopheles gambiae s.l. in Africa" (PI: Professor M. Akogbeto), the "African Network on Vector Resistance to Insecticides" coordinated by the World Health Organization/Regional Office for Africa, and the Pal+ Program from the French Ministry of Research.

Authors' addresses: Josiane Etang, Isabelle Morlais, Philippe Nwane, Mouhamadou Chouaibou, and Frédéric Simard, Organisation de Coordination pour la Lutte contre les Endémies en Afrique Centrale, PO Box 288, Yaounde, Cameroon, Telephone: 237-223-2232, Fax:
237-223-0061, E-mail: simard@ird.fr. Etienne Fondjo and Hamadou Ndjemai, National Malaria Control Program, Ministry of Health, PO Box 14306, Yaounde, Cameroon, Telephone: 237-222-3917, Fax: 237222-3917. Fabrice Chandre, Centre de Recherches Entomologiques de Cotonou, 06 BP 2064, Cotonou, Benin, Telephone: 229-2133-0825, Fax: 229-2130-8860. Cecile Brengues, Institut de Recherche pour le Développement, Research Unit 016, Laboratoire de Lutte contre les Insectes Nuisibles, 911 Avenue Agropolis, BP 64501, 34394 Montpellier Cedex 5, France, Telephone: 33-4-67-04-19-24, Fax: 33-4-6754-20-44.

Reprint requests: Frédéric Simard, Organisation de Coordination pour la Lutte contre les Endémies en Afrique Centrale, PO Box 288, Yaounde, Cameroon, E-mail: simard@ird.fr.

\section{REFERENCES}

1. World Health Organization, 2000. WHO expert committee on malaria. World Health Organ Tech Rep Ser 892: 1-71.

2. Hemingway J, Hawkes NJ, McCaroll L, Ranson H, 2004. The molecular basis of insecticide resistance in mosquitoes. Insect Biochem Mol Biol 34: 653-665.

3. Martinez-Torres D, Chandre F, Williamson MS, Darriet F, Bergé JB, Devonshire AL, Guillet P, Pasteur N, Pauron D, 1998. Molecular characterisation of pyrethroid knockdown resistance $(\mathrm{kdr})$ in the major malaria vector Anopheles gambiae s. s. Insect Mol Biol 7: 179-184.

4. Chandre F, Manguin S, Brengues C, Dossou Yovo J, Darriet F, Diabate A, Carnevale P, Guillet P, 1999. Current distribution of pyrethroid resistance gene $(\mathrm{Kdr})$ in Anopheles gambiae complex from West Africa and further evidence for reproductive isolation of Mopti form. Parassitologia 41: 319-322.

5. Ranson H, Jensen B, Vulule J, Wang X, Hemingway J, Collins F, 2000. Identification of a point mutation in the voltage-gated sodium channel gene of Kenyan Anopheles gambiae associated with resistance to DDT and pyrethroids. Insect Mol Biol 9: 491-497.

6. Etang J, Manga L, Chandre F, Guillet P, Fondjo E, Mimpfoundi R, Toto JC, Fontenille D, 2003. Insecticide susceptibility status of Anopheles gambiae s.l. (Diptera: Culicidae) in the Republic of Cameroon. J Med Entomol 40: 491-497.

7. Gentile G, Santolamazza F, Fanello C, Petrarca V, Caccone A, Della Torre A, 2004. Variation in an intron sequence of voltage-gate sodium channel gene correlates with genetic differentiation between Anopheles gambiae s.s. molecular forms. Insect Mol Biol 13: 371-377.

8. Reimer LJ, Tripet F, Slotman M, Spielman A, Lanzaro GC, 2005. An unusual distribution of $\mathrm{kdr}$ gene among populations of Anopheles gambiae on the island of Bioko, Equatorial Guinea. Insect Mol Biol 14: 683-688.

9. Gillies MT, de Meillon B, 1968. The anophelinae of Africa south of the Sahara. Publ S Afr Inst Med Res 54: 31-343..

10. World Health Organization, 1998. Tests Procedures for Insecticide Resistance Monitoring in Malaria Vectors, Bio-Efficacy and Persistence of Insecticides on Treated Surfaces. Report of the WHO Informal Consultation. Geneva: World Health Organization.

11. Fanello C, Santolamazza F, della Torre A, 2002. Simultaneous identification of species and molecular forms of the Anopheles gambiae complex by PCR-RFLP. Med Vet Entomol 16: 461464.

12. Coetzee M, Craig M, le Sueur D, 2000. Distribution of African malaria mosquitoes belonging to the Anopheles gambiae complex. Parasitol Today 16: 74-77.

13. Wondji C, Simard F, Petrarca V, Etang J, Santolamazza F, della Torre A, Fontenille D, 2005. Species and populations of the Anopheles gambiae complex in Cameroon with special emphasis on chromosomal and molecular forms of Anopheles gambiae s.s. J Med Entomol 42: 998-1005.

14. Lynd A, Ranson H, McCall PJ, Randle P, Black WC IV, Walker ED, Donnelly MJ, 2005. A simplified high-throughput method for pyrethroid knock-down resistance (kdr) detection in Anopheles gambiae. Malar J 4: 16.

15. Diabate A, Brengues C, Baldet T, Dabiré RK, Hougard JM, Akogbeto M, Kengne P, Simard F, Guillet P, Hemingway J, Chandre F, 2004. The spread of the Leu-Phe kdr mutation 
through Anopheles gambiae complex in Burkina Faso: genetic introgression and de novo phenomena. Trop Med Int Health 9: 1267-1273.

16. Yawson AE, McCall PJ, Wilson MD, Donnelly MJ, 2004. Species abundance and insecticide resistance of Anopheles gambiae in selected areas of Ghana and Burkina Faso. Med Vet Entomol 18: $372-377$.

17. Weill M, Chandre F, Brengues C, Manguin S, Akogbeto M, Pas- teur N, Guillet P, Raymond M, 2000. The Kdr mutation occurs in the Mopti form of Anopheles gambiae s.s. through introgression. Insect Mol Biol 9: 451-455.

18. Awolola TS, Oyewole IO, Amajoh CN, Idowu ET, Ajayi MB, Oduola A, Manafa OU, Koekemoer LL, Coetzee M, 2005. Distribution of the molecular forms of Anopheles gambiae and pyrethroid knock down resistance gene in Nigeria. Acta Trop 95: 204-205. 